\title{
Il Romanzo di Folco Fitz Waryn (Fouke Fitz Waryn), traduzione e commento a cura di Margherita Lecco
}

\section{Walter Meliga}

\section{(2) OpenEdition}

1 Journals

\section{Edizione digitale}

URL: http://journals.openedition.org/studifrancesi/1251

DOI: 10.4000/studifrancesi.1251

ISSN: 2421-5856

\section{Editore}

Rosenberg \& Sellier

\section{Edizione cartacea}

Data di pubblicazione: 1 décembre 2015

Paginazione: 564

ISSN: 0039-2944

\section{Notizia bibliografica digitale}

Walter Meliga, «ll Romanzo di Folco Fitz Waryn (Fouke Fitz Waryn), traduzione e commento a cura di Margherita Lecco», Studi Francesi [Online], 177 (LIX | III) | 2015, online dal 01 décembre 2015, consultato il 06 janvier 2021. URL: http://journals.openedition.org/studifrancesi/1251 ; DOI: https:// doi.org/10.4000/studifrancesi. 1251

Questo documento è stato generato automaticamente il 6 janvier 2021.

\section{(c) $(1) \ominus$}

Studi Francesi è distribuita con Licenza Creative Commons Attribuzione - Non commerciale - Non opere derivate 4.0 Internazionale. 


\title{
Il Romanzo di Folco Fitz Waryn (Fouke Fitz Waryn), traduzione e commento a cura di Margherita Lecco
}

\author{
Walter Meliga
}

\section{NOTIZIA}

Il Romanzo di Folco Fitz Waryn (Fouke Fitz Waryn), Edizione, traduzione e commento a cura di Margherita LECCO, Alessandria, Edizioni dell'Orso, 2012 («Testi della Letteratura Anglo-Normanna», 1), pp. 220.

1 Nuova edizione (e prima italiana) del romanzo sulla base di quella del 1975 a cura di E.J. Hathaway-P.T. Ricketts-C.A. Robson-A.D. Wilshere (Oxford, Blackwell, 1975 [«AngloNorman Text Society», 26-28]) ma con revisione sull'unico manoscritto (Londra, British Library, Royal 12), accompagnata dalla traduzione italiana e preceduta da una buona introduzione sugli aspetti letterari e linguistici del testo. Il lavoro è particolarmente apprezzabile, soprattutto in relazione all'articolata strutturazione del romanzo (già nella perduta versione in versi) e alla particolare forma linguistica, che denuncia il progressivo ingresso dell'inglese. All'introduzione seguono due appendici, l'una dedicata alla ricostruzione dei passaggi in versi a partire dalla redazione prosastica, l'altra agli eventi e personaggi e ai luoghi presenti nel romanzo. L'edizione è completata da un indice dei nomi e da un glossario. 